\title{
SPHINX ATROPOS.
}

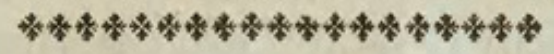 \\ CHARACTER GENERICUS.}

Antennce subprismaticæ, utroque fine attenuatæ. Lingua exserta (plerisque.)

Palpi duo reflexi.

Ala deflexæ.

Character SPECificus, $\Theta^{\circ}$.

SPHINX alis primoribus griseis, posterioribus abdomineque luteis nigro-fasciatis, thorace macula craniolari flava.

SPHINX alis integris: posticis luteis fasciis fuscis, abdomine luteo cingulis nigris.

Lin. Syst. Nat. p. 799.

Varias Europæ regiones incolit formosissimum hoc insectum, et e rarissimis est lepidopteris quæ in Britannia aluntur. Hujus larva solani tuberosi nec uon jasmini folia præ cæteris amat, et cum noctu præcipue vescatur, interdiu deliteat, eo fit ut difficilior sit detectu quam aliæ pleræque larvæ lepidopterorum. Mense Augusto, chrysalidis vices subitura sub humo se condit, unde mense Septembri insequentis anni prodit ipsa Sphinx, thoracem habens macula 
macula insignitum cujus possit esse quædam imaginaria similitudo cum cranio arido mortui hominis ut vulgo depingitur; quam ob causam, emissamque vocem stridulam, si quis tangendo irritaverit, indoctæ plebi magnum non raro timorem incutit quasi male ominata, et mortis prænuncia: immo narrat celeberrimus Reaumurius ipsas monachas Gallici cujusdam coenobii subitanea trepidatione fuisse perculsas visa Sphinge quæ vespertina per fenestras involaverat.

Quod commune est aliis plerisque insectis, coloribus vel saturatioribus vel pallidioribus variat Sphinx Atropos. 


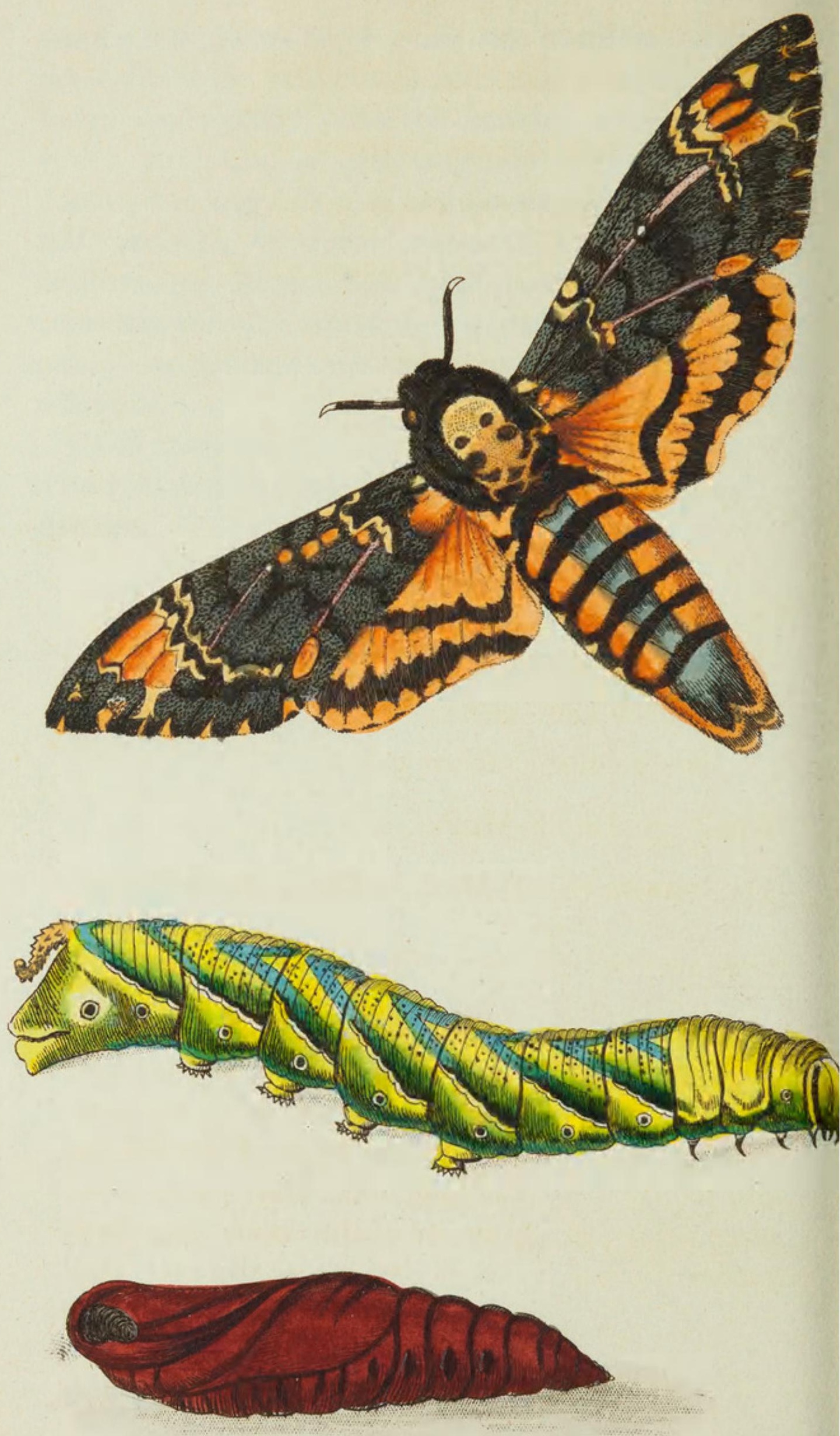


\section{THE \\ JASMINE SPHINX.

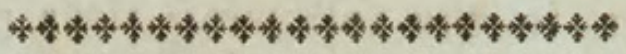 \\ GENERIC CHARACTER.}

Antenna subprismatic, attenuated at each extremity.

Tongue generally exserted.

Feelers two, reflex.

Wings deflected.

\section{SPECIFIC CHARACTER, EंC.}

SPHINX with the upper wings grey, the lower wings and abdomen deep yellow barred with black, and the thorax marked by a scull-shaped yellow patch.

The Tiger Hawk-Moth.

TheJasmineHawk-Moth, orDeath-Head Sphinx.

This highly beautiful insect is a native of many parts of Europe, and is numbered among the rarer species of British lepidoptera. The larva or caterpillar is observed to prefer the leaves of the Jasmine and the Potatoe to those of most other plants; and as it feeds principally by night, concealing itself during the day, is much less frequently seen than 
most other insects of its tribe. It retires under ground in the month of August, in order to undergo its change into a chrysalis, from which, in the month of September in the following year proceeds the complete insect, which is distinguished by a remarkable spot or patch on the thorax, bearing an imaginary resemblance to the figure of a scull or death'shead, as vulgarly represented. From this circumstance, joined to the stridulous tone which it utters when handled or irritated, it has been considered by the vulgar as an animal of ill omen, and as a messenger of fate. The celebrated Reaumur informs us that the members of a female convent in France were seized with general consternation on discovering one of these insects, which had accidentally flown in at one of the open windows during the evening. Like most other insects, it occasionally varies somewhat in colour, being darker or lighter in different individuals. 


\section{$2 \mathrm{BHL}$ Biodiversity Heritage Library}

Shaw, George. 1801. "The Jasmine Sphinx, Sphinx atropos [PI. 528]." The Naturalist's Miscellany 13(CXLVIII), https://doi.org/10.5962/p.310974.

View This Item Online: https://www.biodiversitylibrary.org/item/281546

DOI: https://doi.org/10.5962/p.310974

Permalink: https://www.biodiversitylibrary.org/partpdf/310974

\section{Holding Institution}

Museums Victoria

\section{Sponsored by}

Atlas of Living Australia

\section{Copyright \& Reuse}

Copyright Status: Public domain. The BHL considers that this work is no longer under copyright protection.

This document was created from content at the Biodiversity Heritage Library, the world's largest open access digital library for biodiversity literature and archives. Visit BHL at https://www.biodiversitylibrary.org. 